\title{
Learning Process Based On Character Education In Natural School In Semarang City
}

\author{
Tri Suminara, Liliek Desmawati \\ Universitas Negeri Semarang, Semarang, Indonesia \\ e-mail: atri.suminar@mail.unnes.ac.id
}

\begin{abstract}
This study aims to describe the process of learning based on character education in natural schools. This research method is designed with qualitative research. Research subjects are early childhood education teacher in Ar-Ridlo Nature School Semarang City. Data collection by in-depth interview method, observation and documentation. Validity of data with honesty reliability, observational persistence, triangulation of sources and methods, comprehension. Analysis of interactive model data. The results showed that the nature school in Semarang City placed teachers as learning managers with duties ranging from arranging lesson plans, organizing school resources, implementing up to evaluating learning as a form of supervision. Teachers act as motivators, facilitators, mentors, modeling and students as active learning subjects. The character education system in the natural school through integrated learning in the thematic form or the net web of themes (spider web), creating a green learning environment as a science research laboratory, through gardening activities, raising, applying character-based learning as harmonization with the environment Social culture, through habituation and exemplary, inquiry based learning as a scientiest or scientist through the approach of "scientific and multiple intelligence based learning", children are given free space creative and expression in accordance with the field of intelligence of each child. Assessment of learning includes cognitive, affective and psychomotor aspects through test and non-test techniques that teachers do by involving parents.
\end{abstract}

Keywords: $\quad$ Learning Process, Character Education, Natural School

\section{INTRODUCTION}

Education is a strong milestone to alleviate the poverty of knowledge, solve the problem of ignorance, and solve all the problems of the nation that has been going on. The role of education is clearly a significant and central thing because education provides the opening and extension of knowledge so that the nation is truly literate on the life of the nation and state. Education is presented to bring this nation into a civilized and cultured nation. Education was born to repair the depravity that has been clothed in all the joints of life of this nation [1].

National education is considered failed in shaping the character / character and moral of the nation's children. Schools have not yet succeeded in giving birth to noble virtuous children. Therefore, there must be a need to change that is how approaches, methods and strategies used to achieve these noble goals. It is because of this that actually determines the effectiveness and efficiency of personality formation of the human child.

Character education is the answer to the education system in Indonesia that emphasizes the cognitive aspect rather than the emotional, social, motor, creativity, imagination and spiritual aspects. According to the existing system of early education is too oriented to the development of the left brain (cognitive) and less attention to the development of the right brain (affective, empathy and taste). In fact, character development is more related to the optimization of right brain function. Character building must be done in a systematic and continuous manner involving "knowledge, feeling, loving, and acting".

Character education as a top priority in the development of the nation's hope is able to restore the function of education, that is not only to build intellectual intelligence, but also to make Indonesian human noble character. The character of the nation is an important aspect of the quality of human resources because the quality of the nation's character determines the progress of a nation. A person's personal character is largely shaped by his education. Therefore, to form a person who is praiseworthy, impeccable, and responsible is absolutely necessary quality education. To start with is to build characters [2].

Character is the basic value of behavior that becomes the reference value of interaction between 
humans. This concept explains the character as identity. Universally, various characters are defined as the value of life together based on pillars: peace, respect, cooperation, freedom, happiness, honesty, humblelity, Love, love, responsibility, simplicity, tolerance, and unity. The scope of the characters is very broad and deep, UNESCO has done the study and concluded there are six characters that are universal that can be accepted by all religions and any nation. The value of the character is (1) Trustworthiness, ie the trustee: honest, reliable, courageous, (2) Respect, people who appreciate: civilized, polite; (3) Responsibility, the responsible person, (4) Fairness, the fair / open person, (5) Caring, the person who cares, (6) Citizenship, a good citizen.

Characters other than influenced by heredity, are also influenced by the environment. The social environment and the natural environment contribute to the formation of one's character. A child living in a harsh social environment, such as in a densely populated, metropolitan area, usually tends to behave in an antisocial, loud, emotional manner and so on. Meanwhile, children living in arid, hot, and barren environments, in general, also have a strong temperament as well. Based on the above thoughts of understanding the character can be interpreted as the basic values that build a person, formed both because of the influence of heredity and the influence of the environment, which distinguishes it from others, and embodied in his attitude and behavior in everyday life.

Schools as educational institutions are now more busy with the academic side so that students get high marks. The existence of moral values and character begins to be questioned again [2]. Education has so far only emphasized intellectual intelligence and seemed to ignore the existence of another much more important intelligence. The attitude of honesty, commitment, tenacity, hard work to piety as if out of education problems. The school of nature is a reaction to the emergence of a critical education that makes the learner an active subject of learning, not the 'parrot' of the words of his teacher or of the textbook. Education is not just about transferring knowledge, but as a description of reality, education that connects between knowing and then 'changing' reality. In the end, the educational process is able to deliver the students in finding answers to the problems faced that have not yet thought of the solution, the education to face the problem.

Character education is a process leading to positive character change, what the teacher does and influences the character of the students he teaches. Character education is a conscious and earnest effort of a teacher to teach the values to his students [3]. Character education is an education that develops the noble character (good character) of the learner by practicing and teaching moral values and civilized decision making in relation to fellow human beings as well as in relation to his God [4]

The Ministry of Education in Indonesia formulates the character education materials in schools includes 18 values of character (1) Religious, (2) Honest, (3) Tolerance, (4) Discipline, (5) Hard work, (6) Creative, (7) independent, (8) Democratic, (9) Curiosity, (10) Spirit of nationality, (11) Love of the country, (12). Appreciate achievement, (13) Friendly or communicative, (14) Peaceful love, (15) Fond of reading. (16) Caring for the environment, (17) Social Care and (18) responsibility. Children will grow into a good character if living in a social environment of character and requires awareness of all parties that affect the child's life (family, school, and all components of society-religious institutions, sports associations, business communities, etc.) that Character education is vital to do [5].

The process of character education in natural schools is different from formal education system. Learning in the natural school implements an open social system that is dominantly influenced by environmental factors. As explained by Vygotski, the socio-cultural environment is crucial to the learners' learning outcomes. Based on this thought, it is important to study in depth the process of character education education in natural school.

Learning that implements character education in schools can be pursued through four integrated strategy alternatives: (1) integrating character education content that has been formulated into all subjects, (2) integrating character education into daily activities at school, (3) ) Integrating character education into programmed or planned activities, and (4) building communication and cooperation between schools with parents of learners. The commitment of teachers in the implementation of character education in the school of nature, among others, is (1) to socialize character education and commit together among all components of the school community (educators and education staff and school committee), (2) make commitment with all stakeholders, Parents, students, committees, and local community leaders) to support the implementation of character education; (3) conduct context analysis on school conditions (internal and external); (4) arrange school 
action plans related to character education values, 5) make the planning and implementation program of character education, (6) perform conditioning such as: the provision of exemplary means of appreciation and empowerment, and (7) conduct success and supervision assessment.

\section{METHODS}

\subsection{Research Design}

This study aims to gain an in-depth description of the management of the implementation of character education in a natural school with a qualitative approach of data collected from a natural setting as a direct data source [6]. This research is expected to find as well as describe the data as a whole and intact about the management of the implementation of character education in natural schools. The natural school that became the object of this research is the Ar-Ridho Nature School Semarang located in the urban area.

\subsection{Research Procedures}

The qualitative research procedure is interactive, taking place in an overlapping circle. The data collection strategy is flexible, with the following steps: (a) Planning, including the formulation and limitation of the problem and formulating the questions directed for data collection. (B) Begin data collection by initiating good relationships, fostering credentials and intimate relationships with the individuals and groups that are the source of the data. (C) Collection of baseline data, carried out with more in-depth interviews, intensive observation and documentation. (D) The collection of closing data, conducted if all information is required, no new data is found. (E) Complete, undertaken to refine the results of data analysis and prepare how to present it.

\subsection{Data Source}

The primary data source is Educator School of Nature Ar-Ridho Semarang. While secondary data sources are documents related to biodata (characteristic) learners, educators and managers, vision and mission of schools, education programs, curriculum, lesson plans, materials and evaluation of learning outcomes.

\subsection{Data Collection Technique}

Data collection techniques used in qualitative research are multi-technique, namely (1) observation, which is done in the form of special observation. Observations were made during the learning process, both in school and outside school during school hours. (2) interviews, conducted on the relevant parties, ie education managers (foundations), principals, educators, learners and employees of the natural school. Interviews are conducted informally and formally structured. (3) documentation, by searching documentary data in the form of daily journal of educator, curriculum, learning tool in syllabus form, lesson plan, learning result assessment instrument, study result document, student job portfolio.

In the process of collecting data pay attention to: (1) the validity of data that refers to trustworthiness and understanding, (2) reliability, data obtained honestly, earnestly and thoroughly, (3) usability, pointing to the relevance of the findings With users of research, (4) ethics, which concerns relational ethics for the common good, ecological ethics that puts the good in the community environment, culture and work system, and maintains the confidentiality of good names and avoids negative impacts.

\subsection{Data Analysis}

The research design of this action uses a qualitative approach, therefore the data analysis is narrative-qualitative. The technique of analyzing the qualitative narrative data as follows: (1) identifying the collected themes inductively, (2) generating the code of interview result, observation in each data group, (3) making systematic data to form one unity meaning, , (4) making an organizational review of each course unit, (5) drafting a concept map of related factors and the consequences of something, (6) analysis of preceding and following factors, (7) making forms of presentation of the findings Which are presented in tables, graphs, (8) identifying the undiscovered, (9) interpretation of data by linking the results of the analysis with literature or literature review relevant to the research problem.

The form of data analysis is described as the dominant analysis of pattern matching, namely the use of patterned patterning logic based on empathy with predicted patterns. If this pattern has any similarities, then the results can corroborate the internal analysis of the case study concerned [7].

\section{RESULTS AND DISCUSSION}

\subsection{Research Results}

Schools of nature are known as character schools or character-based schools. Sekolah Alam Ar-Ridho Semarang conducts character-based learning supported by 1 teacher of play group, 4 kindergarten teachers, 18 elementary teachers and 29 junior high school teachers and 12 employees to 
serve students of 533 people. The natural school environment is conditioned as a source and learning medium. Looks shady environment, lush and green and interspersed with ornamental plants and small gazebo / saung in some places around the natural school location. Besides, there are perennials that are designed to form a natural and simple forest atmosphere as a harmonious ecosystem. Free study space from the thick walls of buildings that separate the child with the natural atmosphere. The adhesive or the study room wall made of woven bamboo is designed with a beautiful art value dipengi with wood wood in a very natural form

In the natural school environment there is a garden as a green laboratory (green laboratory). Children use laboratories where scientific activities, entreprenuership, sensitivity to the environment and as a learning space that has the freedom to interact and express during the learning process:

\section{Sekolah Alam.}

1). Learning character education planning at

Character values developed at Ar-Ridho Semarang natural school are superior characters that include: (1) scientific character, (2) leadership character, (3) entrepreneurial character, (4) noble moral character (akhlaqul karimah). All character values are based on Islamic principles. The uniqueness of each child in the frame of multiple intelligences to be part of the philosophy to be achieved. Teachers' efforts to improve the character of children (aqidah Islamiah, akhlaqul karimah, scientific thinking, leadership spirit, entrepreneurship spirit and love environment), both for students who are still in early childhood and those already in elementary school, teachers are always preparing lesson plans. Preparation techniques between early childhood teachers with elementary teachers there are differences. Preparation of lesson plans in early childhood is done by teachers in groups (two teachers one lesson plan) because the learning is done in the form of team (core teacher and teacher aids). Form of planning in early childhood is SKH (Daily Activities Unit) and SKM (Weekly Activity Unit). While the preparation of lesson plans in elementary school conducted independently based on school signs, then coordinated with other teachers who are coordinated by the principal. The reason for the preparation of the plan independently is that each teacher is required to develop a learning implementation plan for the learning in different classes. Each teacher is responsible for learning in one class.
Preparation of character-based learning in the form of RPP (learning implementation plan), at ArRidho Nature School Semarang covers the preparation of complex teachers, namely: (1) formulating learning objectives, (2) preparing material / teaching materials, (3) Learning, (3) preparing learning infrastructure, (4) preparing media or teaching aids, (5) preparing assessment instruments.

\section{2). Implementation of Character Education} Learning at School of Nature

Beginning the learning process in play group, kindergarten and elementary school classes, teachers motivate, stimulate through real problem orientation, can be observed in the environment. The teacher conditions the students to learn through the giving of appersepsi (linking the material to be learned with the learning experience of learners that have been obtained previously). The teacher uses focused questioning techniques.

Teachers manage the facilities and learning infrastructure needed to develop the character of learners during the learning process together or in groups and involve the students in turns. Facilities and infrastructure to develop character in the school of nature include: gazebo group learning and art performances, computer labs, audiovisual laboratories, libraries, science laboratories, vegetable gardens, rabbit pens, chicken coops, hydroponic garden various fruit plants, vegetables and flowers Ornamental, compost cages and school cooperatives. The learning that is applied to develop the character values in the natural school integrates the students in the process of character building activities through the character process cycle which includes exemplary, awareness, habituation and motivation that are attached to each learning activity. (2) an integrative learning system, often referred to as "web spider". The interconnectedness between science both sciences and social sciences is given as a provision for learning experiences to build a holistic understanding of the nature of science with character. Children become sensitive and open in listening to problems and looking for total problem solving.

Invention-based learning model, teachers build learning atmosphere with the format that each student is given a predicate of a scientist. The teacher invites the child to investigate an object with curious curiosity. Learning is structured with exploratory and investigative approaches to objects and events that encourage and direct students to 
search and seek knowledge directly with the process of "scientific" skills. The process of scientific skills is to develop the value of scientific characters by following the sequence of activities: (a) begins to observe and collect data and classify through classification. (b) continued activities to ask, always curious behind the meaning of objects or events that appear, so that the solution to the problems faced through the process of investigation and experiment. (c) Guided children can formulate a hypothesis, that is, to train the alleged construct of the problem studied. (d) after the information or data collected children are guided to draw a logical conclusion based on the results of reasoning in the form of predication or interpretation of the data collected. (e) the last teacher guides the children to convey information, findings of his thoughts through pictures, graphics, tables or other media as report documents. (4) Learning system with a philosophy based on green (green based learning). Teachers facilitate students to learn (a) green school environment such as mini forest, garbage bank, vegetable garden, crop planting, healthy canteen; (b) green construction such as energy saving, walking, and (c) green media such as organic, reuse, down and recycle.(d) educator as mentor, (e) educator as facilitator and educator as motivator, (f) learners play an active role as subject of learning. When learning is underway in elementary and early childhood in Ar-Ridho shows the process of learning interaction between learners with educators interrelated (multiarah) and open, direct communication. Learning outside the classroom requires parental help to monitor children's activities. The school provides a schedule of school activities to parents since the first semester and programmed for one semester.

The children at the Ar-Ridho Natural School in Semarang are learning in a happy, unpressive, free and active atmosphere. Innovative ideas of children in the learning process grow with their creativity. All children's learning activities are under the guidance and attitude and attitude of the teacher, both in the classroom and outside the classroom. Educators are always friendly, respecting learners and recognizing potential children, supporting familiar, familial relationships.

Teachers organize learners during the learning process to develop character through conditioning: (a) together (mass) through the provision of questions, memorization. (b) in groups through working on the problems done in groups, (c) individually through doing homework in the rum.

\subsection{Discussion}

Character values developed at natural schools in Semarang city, the character of scientific thinking development through scientific approach, character of leadership, entrepreneurial character, character of environmental love and character of akhlaqul karima based on Islamic values. The types of character values developed in this school of nature correspond to the concept of character as the values of human behavior associated with God Almighty, self, fellow human being, environment, and nationality embodied in thoughts, attitudes, feelings, words, And deeds based on religious norms, law, orderliness, culture, customs, and aesthetics. [3]

Preparation of individual and group plans under the coordination of the principal. Each character value is planned integrated into the subject through different learning methods. This finding is in accordance with the concept of learning planning functions undertaken to determine the various objectives, strategies, and directions to be achieved in the learning objectives [8]. Character education in natural schools is conducted by classroom teachers (PAUD and SD), there is a division of roles between educators, learners, parents, school employees and school leaders in learning: (a) educators as model models, (b) educators as mentors, (c) educators as facilitators and motivators; (d) learners play an active role as subject of learning; (e) parents as motivators, facilitators and evaluators (f) principals as managers who manage all school program activities including character learning. These findings indicate the function of organizing in character learning, with the characteristics of the organizing act of determining the principal activities, grouping activities into positions, grouping positions and assigning responsibilities, filling positions with appropriate people. Even character education in this natural school has collaborated between schools with parents of learners, with other related parties [9].

Implementation of character learning in natural schools implements a learning system with innovative and creative methods. The school of nature creates a green learning environment as a science research laboratory, character-based learning as harmonization with the socio-cultural environment, through habituation and exemplary, 
inquiry based learning as scientiest or scientist and multiple intelligent based learning, the children are given free and creative space Expression in accordance with the field of intelligence of each child and through integrated learning in the thematic form or the web nets theme (spider web). All of these innovative learning systems are implemented in accordance with character education guides, which include: (1). Through routine activities, (2). Spontaneous activity, (3). Exemplary, and (4). Through conditioning [2]. The four methods have been implemented on character learning in natural schools. The application of character education in natural schools is pursued through four integrated strategy alternatives: (1) integrating character education content that has been formulated into all subjects; (2) integrating character education into daily activities at school; (3) integrating Character education into programmed or planned activities, and (4) building communication and cooperation between schools with parents of learners [10].

Character-based learning evaluation is done by classroom teachers through process assessment and end of learning with observation techniques, anecdotal notes and interviews. Assessment instruments in the form of tiered scales 5, diaries and non-structured interview guidelines. This assessment technique and instrument shape is particularly appropriate for measuring the tangible character of attitudes, innate behaviors, and behavioral outcomes, which builds a person's personality [11]; [12]. Integrated process assessment techniques in learning as well as the finding of an integrated character education model [13]. The result of the learning appraisal is used as a reflection material, improving teacher performance.

\section{CONCLUSIONS}

The character values developed in the ArRidho natural school of Semarang are the character of the development of scientific thinking through scientific study, leadership character, entrepreneurial character, the character of environmental love and the character of akhlaqul karima based on Islamic religious values.

Learning planning in the form of selfdeveloped RPP (SD teachers) and in the form of SKH (Daily Activities Unit) and SKM (Weekly Activities Unit) in groups (PAUD teachers), are guided by the principal in charge. Aspects of planning include the formulation of objectives, the selection of relevant materials, planning of learning strategies, selection of techniques and the form of learning evaluation instruments.

The implementation of character-based learning is integrated with all subjects, every day all done, character education materials integrated with everyday life and integrated in all school program planning. There is a collaboration between school and parent learners, every 2 weeks or situational done by parents involved in managing learning in school and cooperation with world age and industry as source of learning. Natural school learning process creates a green learning environment as a science research laboratory, through gardening activities, raising, applying character based learning as harmonization with socio-cultural environment, through habituation and modeling, inquiry based learning as scientiest or scientist through a scientific approach And multiple intelligence-based learning, children are given free space of creation and expression in accordance with the field of intelligence of each child and through integrated learning in the thematic form or web nets theme (spider web).

Character-based learning evaluation is done by classroom teachers through process evaluation and end of learning that includes cognitive, affective and psychomotor aspects with test, observation, anecdotal and non structural interview.

\section{REFERENCES}

[1] Yamin, Mohammad. 2008. Menggugat Pendidikan Indonesia Belajar dari Paulo Freire dan Ki Hajar Dewantara. Malang: ArRuzmedia

[2] Kementerian Pendidikan Nasional, Badan Penelitian dan Pengembangan, Pusat Kurikulum, 2011, Pengembangan Pendidikan Budaya dan Karakter Bangsa Pedoman Sekolah. Jakarta: Pusat Kurikulum

[3] Samani, Muchlas dan Hariyanto. 2011. Konsep dan Model Pendidikan Karakter, Bandung : PT Remaja Rosda Karya.

[4] Muslich, Masnur. 2010. Pendidikan Karakter Menjawab Tantangan Krisis Multidimensional. Malang: Bumi Aksara.

[5] Zuchdi, D. Zuhdan, K. Muhsinatun, S. 2013. Model Pendidikan Karakter Terintegrasi dalam Pembelajaran dan Pengembangan Kultur Sekolah. (Laporan Penelitian Hibah Pascasarjana). PPS Universitas Negeri Yogyakarta. 
[6] Matthew B. Miles \& A.Michael Huberman, 1992. Analisis Data Kualitatif. Jakarta: UIPress.

[7] Yin, Robert, K.1996. Studi Kasus: Desain dan Metode. Terjemahan M. Djauzi Mudzakir. Edisi Revisi. Jakarta: Raja Grafindo Persada.

[8] Usman, Husaini. 2011. Manajemen: Teori, Praktik, dan Riset Pendidikan: Jakarta: Bumi Aksara.

[9] Kusdi. 2009. Teori Organisasi dan Administrasi. Jakarta: Salemba Humanika.
[10] Mulyasa. 2012. Manajemen Pendidikan Karakter. Cetakan ke-2. Jakarta: Bumi Aksara.

[11] Prayitno, Belferik Manulang. 2010. Pendidikan Karakter dalam Pembangunan Bangsa. Cetakan I. Medan: Pascasarjana Universitas Negeri Medan.

[12] Chatib, Munif. 2011. Gurunya Manusia: Menjadikan Semua Anak Istimewa dan Semua Anak Juara. Bandung: Kaifa.

[13] Sagala, Syaiful. 2010. Manajemen Strategik Dalam Peningkatan Mutu Pendidikan. Bandung: Alfabeta. 